Scottish Geographical Magazine

\title{
Mining development in Spitsbergen
}

\section{R.N. Rudmose Brown D.Sc.}

To cite this article: R.N. Rudmose Brown D.Sc. (1922) Mining development in Spitsbergen, Scottish Geographical Magazine, 38:2, 115-117, DOI: $10.1080 / 14702542208554239$

To link to this article: http://dx.doi.org/10.1080/14702542208554239

\section{曲 Published online: 30 Jan 2008.}

Submit your article to this journal ๘

\section{山 Article views: 4}

Q View related articles $\longleftarrow$ 
rising to new responsibilities, proud of its growing partnership in our Empire. If we continue wisely on this course, and if we steadily and sympathetically remember the causes which have retarded India's progress in the past, her future should be secure and her association with us should be established on a firmer, more cordial, and more durable basis than ever before.

\section{MINING DEVELOPMENT IN SPITSBERGEN.}

By R. N. Rudmosie Brown, D.Se.

Consinerable developments in Spitsbergen coal-mining have taken place during the last two years, and by this time probably all the accessible coal-seams on the west coast and around Ice Fjord have been investigated and claimed. The Spitsbergen Treaty, previously referred to in this Magazine (April 1920), still awaits ratification, having been delayed by long discussion over the mining regulations, which are to form an integral part of the treaty. As a result Spitsbergen is still a no-man's-land and Norwegian sovereignty is not yet operative. While subjects of all nations are, under the provisions of the treaty, to be given ample facilities to secure land for legitimate mining, the wholesale claiming of estates will be discouraged. Occupants of estates whose tenancy antedates the operation of Norwegian sovereignty are to be accorded special privileges with regard to their land. It is hoped that the treaty will be ratified this year, in which case the international Spitsbergen conference to be called at Copenhagen may be ablo to adjudicate on disputed claims before the opening of the summer of 1923 .

The Dutch, after an absence from Spitsbergen since the whale-fishing days of the seventeenth century, have reappeared on the scene. ${ }^{1}$ Acquiring land in 1920 at Cape Boheman in Ice Fjord by purchase from Norwegian owners, who had done little or nothing to develop the estate, the Dutch company, now enlarged as the Netherlands Spitsbergen Coal Company, expanded its interest in the following year by the acquisition from Russian owners of a mine on the east side of Green Harbour, and last year was busy exporting coal. The Cape Boheman estate is small in area, difficult of access by reason of shoal water, and contains somewhat poor Jurassic coal, but the Green Harbour mine, which has been in full working order since 1917, has none of these disadvantages. The seam is in the great Tertiary coal-field of central Spitsbergen and the coal is of the same high quality as the Iongyear coal. Its westerly position gives

\footnotetext{
1 Dutch interest in Spritsbergen is shown in the publication of a work on early cartography, The Dutch Discovery and Mapping of Spitsbergen, 1596-1829, F. C. Wieder, Amsterdam, 1919. This volume contains an invalualule collection of eighty-three maps, even if the author does not altogether make good his contention that the Dutch knew most of the Spitsbergen coasts before the British.
} 
Green Harbour a long season of accessibility to shipping. This Company wintered parties of workmen at Cape Boheman in 1920-21 and at Green Harbour in 1921-22. The same coal is being mined in the vicinity of Coles Bay by the Anglo-Russian Company. This mine is in a 55 -inch seam in almost horizontal strata within a stone's throw of the side of Ice Fjord at a height of 230 feet.

The most extensive mining in this Tertiary coal-field is at the Store Norske mines in Longyear Valloy in Advent Bay. The steady growth of this concern since American enterprise began it in 1904 shows the possibilities of Spitsbergen coal-mining. It is now a large settlement with some 500 inhabitants during the height of the summer, and about 300 in winter. An unfortunate accident in January 1920, the first of its kind in Spitsbergen, led to some loss of life and the setting on fire of the old mine on the valley side behind the settlement. As a result efforts were concentrated on the new mine (No. 2) on the opposite side of Longyear Valley at a height of about 900 feet above sea-level. This promises even better coal and certainly a larger output than No. 1 mine. In order to facilitate loading and provide better anchorage than the head of the bay affords, a wire ropeway is being run from the new mine along the side of the fjord for about two and a half miles to Advent Point. Under the lee of the point there is excellent anchorage, while a low-lying raised beach affords an ample site for wharves. Modern coal-loading machinery is to be installed. The new port is expected to be ready this year and to handle an annual export of 200,000 tons. Longyear city itself has shown a remarkable growth. This unofficial capital of Spitsbergen now contains many new houses built on improved plans. There are also a new post-office and a new wireless station in the heart of the settlement. Very few of the original small houses now remain ; they have had to make way for new buildings as their sites increased in value. A tourist hotel is suggested at Advent Point, where in 1896-97 there stood the small tourist hut built by Vesteraalen Dampskibselskab.

The mine at Hjorth Haven on the opposite side of Advent Bay is now virtually abandoned. The poorness of the Cretaceous coal, which approaches a lignite in places, and the difficulty of working a mine at a height of 1600 feet, made the projeet unprofitable. The settlement at Hjorth Haven had some historic interest in that it contained many of the $\log$ houses originally erected in 1904 at Advent City in the ill-starred attempt to work the Jurassic coal. This type of log dwelling is now seldom seen in the mining camps of Spitsbergen.

In King's Bay there is a large and thriving Norwegian settlement which has grown since 1917. An outlier of Tertiary coal is easily worked and loaded by reason of safe and early approach by sea and good harbourage. In Bell Sound and Lowe Sound the only striking activities are those of the Svenska Spetsbergen Kolfält at the mouth of Braganza Bay. The settlement of Sveagrubbe, as it is called, has grown since its origin in 1917 to a large camp with extensive loading jetties and a railway from the mine. The population is about 200 . The drawback to 
this mine arises from its position. The settlement lies on a rough windswept plain, partly raised beach but mainly glacial moraine, and approach up Lowe Sound is liable to be blocked by ice until late in the season, the outcome both of the southerly position of Bell Sound and the obstacle afforded by Axel Island to the clearance of the ice of Lowe Sound itself. The same company's trial adit in the disturbed strata of Mount Pyramid on the west of Klaas Billen Bay seems to have been abandoned. There is no other Swedish activity in Spitsbergen. The Norwegian mine on Bear Island continues to export in spite of loading difficulties. The coal is Carboniferous.

Several other mining companies have been actively prospecting their estates and proving their coal-seams, with the result that the accessible coal content of Spitshergen has been materially increased, chiefly by the addition of large areas of high-grade Carboniferous coal. A revised estimate, on the conservative side, of the accessible coal content of Spitsbergen is $10,000,000,000$ tons. As geographical circumstances decide that the coal must go in the main to Norway, Sweden, Finland (by its new Arctic seaboard), and Arctic Russia, it is of interest to note that the normal total coal imports of the first three of these countries are : Norway, 2,500,000 tons; Sweden, 4,700,000 tons; Finland, 600,000 tons. Spitsbergen has therefore abundant coal to supply these countries for many centuries. The following figures give, as near as can be ascertained, the coal output of Spitsbergen, including Bear Island, since the War : 1919, 90,000 tons ; $1920,130,000$ tons ; $1921,210,000$ tons. The last year's total would have been larger if the Longyear mine had been in full working order. ${ }^{1}$ The number of miners wintering in Spitsbergen in 1920-21 rose to over 1000 , while the summer population last year must have been well over 1500 . All the large mining settlements are now in wireless communication with the long-range station at Green Harbour.

Along with these economic developments exploration has made some progress, the important work being again done by Norwegian survey parties under Mr. A. Hoel. The last two summers they have been working between Van Mijen's Bay, Horn Sound, and South Cape, a region previously little known except in so far as the Russian Arc of Meridian expedition some twenty years ago had fixed some salient points and made some soundings in adjacent waters. The excellence of this Russian work has been too often overlooked, largely because it was published only in outline. The completed charts are believed to have been prepared but lost before publication in the Russian upheaval of 1917 . Some of Mr. J. Mathieson's surveys and soundings have been incorporated in the newest edition of the Admiralty Charts.

1 For earlier figures see "Receut Developments in Spitsbergen," R. N. Rudmose Brown, Scottish Geographical Magazine, A pril 1920. For information about the economic development of Spitsbergen reference may be made to the following, among other recent works: Spitsbergen-Norge, G. Isachsen, Kristiania, 1921; "Coal-Mining in Spitsbergen," H. M. Cadell, Trans. Inst. Mining Eng., 1x. 2, pp. 119-142 (1920), and En Ferd til Spitsbergen, F. Nansen, Kristiania, 1920. Major Isachsen's pamphlet contains the text of the Spitsbergen Treaty in Norwegian. 